Makale Geliș | Received: 21.09.2021

Makale Kabul | Accepted: 11.10.2021

DOI: $10.18795 /$ gumusmaviatlas. 998457

Mavi Atlas, 9(2)2021: 133-147

Araştırma Makalesi | Research Article

\author{
Mehmet ÜZÜLMEZ \\ Dr. Öğr. Üyesi | Asst. Prof. \\ Gümüşhane Üniversitesi, Edebiyat Fakültesi, Coğrafya Bölümü, Gümüşhane-TÜRKIYYE \\ Gumushane University, Faculty of Literature, Department of Geography, Gumushane-TURKEY \\ ORCID: 0000-0001-9116-0090 \\ mehmetuzulmez@gumushane.edu.tr
}

\title{
Ahmetli (Manisa) İlçesinde Arazi Örtüsünün/Kullanımının Zamansal Değişimi (1995-2015)
}

$\ddot{\mathrm{O} z}$

Günümüz dünyasında insanoğlunun ihtiyaçları devamlı artmaktadır. Bu durum ise yeryüzünde kullanılan arazi yapısının sürekli değişimine sebep olmaktadır. Aynı şekilde Türkiye'de de araziler, amacı dışında kullanıldıklarından dolayı değişimlere uğramıştır ve hâlâ bu değişim süreci devam etmektedir. Türkiye'nin verimli arazileri üzerinde yer alan Ahmetli ilçesindeki arazi örtüsü/kullanımı, geçmișten günümüze değişime uğramıştır. Ahmetli ilçesi, Ege Bölgesi’nin Asıl Ege Bölümü’nde yer almaktadır. İlçe arazisinin büyük bölümünü, üzerinde tarımsal üretimin yapıldığ1 verimli arazi olan Gediz Ovası oluşturmaktadır. Bu çalışmada Ahmetli ilçesinin 1995-2015 yılları arasında arazi örtüsünün/kullanımının geçirdiği değişimler uydu görüntüleri yardımıyla zamansal açıdan incelenmiştir. Uydu görüntüleri, NASA'ya ait olan Landsat TM ve OLI isimli uydularından temin edilmiştir. Görüntüler elde edildikten sonra sınıflama işlemlerine tabi tutulmuş ve söz konusu işlem için Coğrafi Bilgi Sistemleri programlarından biri olan ArcGIS kullanılmıştır. Analizler sonucunda, 1995-2015 yıllarında en büyük değişim, \%31'lik azalışla diğer arazi (kayalık, mera, çıplak arazi vb.) grubunda gerçekleşmiştir. Söz konusu yıllarda tarım arazileri \%22, yerleşim alanı \%7 ve orman arazisi \%2 oranında artış göstermiştir. Yerleşim alanının çoğunluğu tarım arazilerinin üzerinde yer alması, yine bu yapıların söz konusu arazilere doğru büyüdüğünü ortaya koymuştur. Tarım ve orman arazilerindeki büyümenin nedeni sulamanın, teknolojinin, ağaçlandırma faaliyetlerinin artmasının yanında, diğer arazi grubunun da bahsedilen gelişmelerle birlikte tarım ve orman arazisine dönüşmesinden kaynaklanmıștır.

Anahtar Kelimeler: Ahmetli, Arazi Örtüsü/Kullanımı, Zamansal Değișim.

\section{The Temporal Change of Land Cover/Use in Ahmetli (Manisa) District (1995-2015)}

\section{Abstract}

In today's world human needs are constantly increasing. This situation causes constant changes in the land structure used in the world. Likewise, the lands in Turkey have undergone changes due to their misuse, and this process of change still continues. In Ahmetli district, which is located on the fertile lands of Turkey, land cover/use has undergone changes since the past. Ahmetli district is located in the Main Aegean Section of the Aegean Region. Gediz Plain, which is the fertile land on which agricultural production is made, constitutes most of the district's land. In this study, changes in the land cover/use of Ahmetli district between 1995 and 2015 were examined in temporal terms with the help of satellite images. Satellite images were obtained from NASA's Landsat TM and OLI satellites. After the images were obtained, they were subjected to classification processes, and ArcHGIS, one of the Geographical Information Systems programs, was used for the process in question. As a result of the analyses, the greatest change occurred in the other land (rocky, pasture, bare land, etc.) group with a proportional decrease of $\% 31$ in the years 1995-2015. In the years in question, agricultural lands increased by $\% 22$, human constructions by $\% 7$, and forest land by $\% 2$. The fact that the majority of human structures are located on agricultural lands revealed again that these structures have grown towards the said lands. The reason for the growth in agricultural and forest lands was the increase in irrigation, technology and afforestation activities, as well as the transformation of the other land group into agriculture and forest land with the mentioned developments.

Keywords: Ahmetli, Land Cover/Use, Temporal Change. 


\section{Giriş}

Günümüzde doğal kaynaklar, insanın sonsuz ihtiyaçları ve nüfus artışının karşısında yetersiz kalmaktadır. Doğal kaynaklar içerisinde ayrıcalıklı konuma sahip olan toprak, tarımsal faaliyetlerden yerleşime kadar geniş bir çerçevede yoğun kullanım baskısıyla karşı karşıya kalmaktadır. Söz konusu bu süreç, toprakların doğal niteliklerinin ve fonksiyonlarının değişmesine yol açmaktadır. Hızlı ve dinamik bir değişim süreci içerisinde olan ülkemizde, arazi kullanım şekillerinde önemli değişimler olmaktadır. Bu hızlı değişim sürdürülebilir ve planlı olmadığında ise ekolojide önemli tahribatlara sebebiyet vermektedir. Yanlış arazi kullanımı olarak nitelenen bu tür uygulamalar, doğal ortam potansiyeline uygun değildir (Gülersoy, 2001, s. 23). Bu nedenle arazi kaynaklarının en iyi şekilde kullanabilmesi için zamansal değişimin ortaya konulması ve sonuçları doğrultusunda da planlamaların yapılması, yönetilmesi gerekmektedir.

Coğrafi Bilgi Sistemleri (CBS) ve Uzaktan Alg1lama (UA) tekniklerinin kullanımı, günümüzde arazi örtüsü/kullanımı değişimi çalışmalarında hızlı bir şekilde artmış ve araştırmalara büyük kolaylıklar sağlamıştır. Arazi örtüsü/kullanımı değişimlerin belirlenmesinde ve rakamsal sorgulanmasında, uzaktan algilamanın büyük önemi bulunmaktadır. Söz konusu bu yöntem sadece sorgulamayı değil, arazi örtüsünün/kullanımının zamandaki değissimin izlenmesine de imkân sağlamaktadır. Teknolojinin gelişmesiyle her geçen gün uydu görüntülerinin çözünürlüğünün daha net hale gelmesi, çalışmaların kalitesini ve güvenirliliğini de arttırmaktadır. $\mathrm{Bu}$ nedenle dünyada olduğu gibi ülkemizde de bu tür çalışmalar hızlı bir şekilde artmaktadır (Özşahin, 2010; Gülersoy, 2013a, 2013b, 2013c, 2014; Demirağ Turan ve Dengiz, 2014; Kaya ve Toroğlu, 2015; Bayar ve Karabacak, 2017; Güre vd., 2009). Bu çalışmalardan biri olan Özdemir ve Bahadır'ın (2008) Yalova ilinde 1992-2007 yılları arasındaki arazi kullanımın zamansal değişimi adlı çalışmasında, orman alanlarının azalmasıyla birlikte yerleşme ve tarım arazilerinin artışını ortaya koymuşlardır. Başka bir çalışmada Uzun ve Somuncu (2013), 1987 ile 2000 yılları arasında Madra Dağı ve çevresindeki arazi örtüsündeki değişimi belirlemişler ve araştırma alanının \%35’lik kısmında değişimin olduğunu tespit etmişlerdir (s.17). Bazı çalışmalarda ise şehir içindeki arazi kullanımının zamansal değişimine odaklanılmıştır (Özdemir vd., 2020).

Ülkemizde gün geçtikçe arazi örtüsü/kullanımı, orman ve meraların tahribinde olduğu gibi çok hızlı bir şekilde değişmektedir. Özellikle verimli tarım alanları, şehirleşmenin (Sandal ve Gürbüz, 2003; Y1lmaz, 2004; Sönmez, 2011; Cengiz vd., 2014; Özcanlı ve Güzel, 2015), sanayileşmenin (Kara, 1988; Arslan, 2018) ve barajların (Arslan ve Ergül, 2014; Bakırc1, 2016) etkisiyle amacı dışında (Yılmaz, 2001), kontrolsüz ve plansız bir biçimde kullanımları, söz konusu arazilerin geri döndürülemeyecek boyutta yok olmalarına sebep olmaktadır. Ülkemizde yer alan bu etkilerin en aza indirilebilmesi için geleceğe dair daha iyi bir planlanmanın yapılması bir zorunluluk teşkil etmektedir.

Bu çalışmada Ahmetli ilçesinin Coğrafi Bilgi Sistemleri ve Uzaktan Algılama teknikleri ile 1995-2015 yılları arasındaki arazi örtüsündeki/kullanımındaki değişimleri belirlemek, bu değişimlerin sonucunda tespit edilen yanlış arazi kullanımlarına karşı çözüm önerilerinin getirilmesi amaçlanmıştır.

\section{Araştırma Sahasının Yeri ve Sınırı}

Manisa ilinin bir ilçesi olan Ahmetli, Ege Bölgesi’nin Asıl Ege Bölümü’nde yer almaktadır. İlçenin doğusunda Salihli, batısında Turgutlu, kuzeyinde Saruhanlı ve Gölmarmara, güneyinde ise Turgutlu ve İzmir'in ilçesi olan Ödemiş bulunmaktadır. Ahmetli ilçesinin yüzölçümü $233 \mathrm{~km}^{2}$ den oluşmaktadır. İlçenin en büyük yerleşim merkezi Ahmetli şehridir (Foto 1). İlçede 16 kırsal yerleşim bulunmakta ve ilçenin kuzeyinde Çal Dağ, güneyinde ise Bozdağ yer almaktadır. İki dağ sistemi arasında bulunan Gediz Ovası, doğu batı doğrultuda uzanmakta ve içinden de Gediz Nehri akmaktadır. Gediz Nehri'nin üzerinde, ovanın sulanabilmesi amacıyla bir adet regülatör yer 
Üzülmez, M. (2021). Ahmetli (Manisa) ilçesinde arazi örtüsünün/kullanımının zamansal değişimi (19952015), Mavi Atlas, 9(2), 133-147

almaktadır. Gediz Ovası'nın güneyinden İzmir-Ankara ulaşımını sağlayan D300 otoyolu ve demiryolu geçmektedir (Şekil 1).

Foto 1: Ahmetli Șehrinin Güneyden Görünümü.

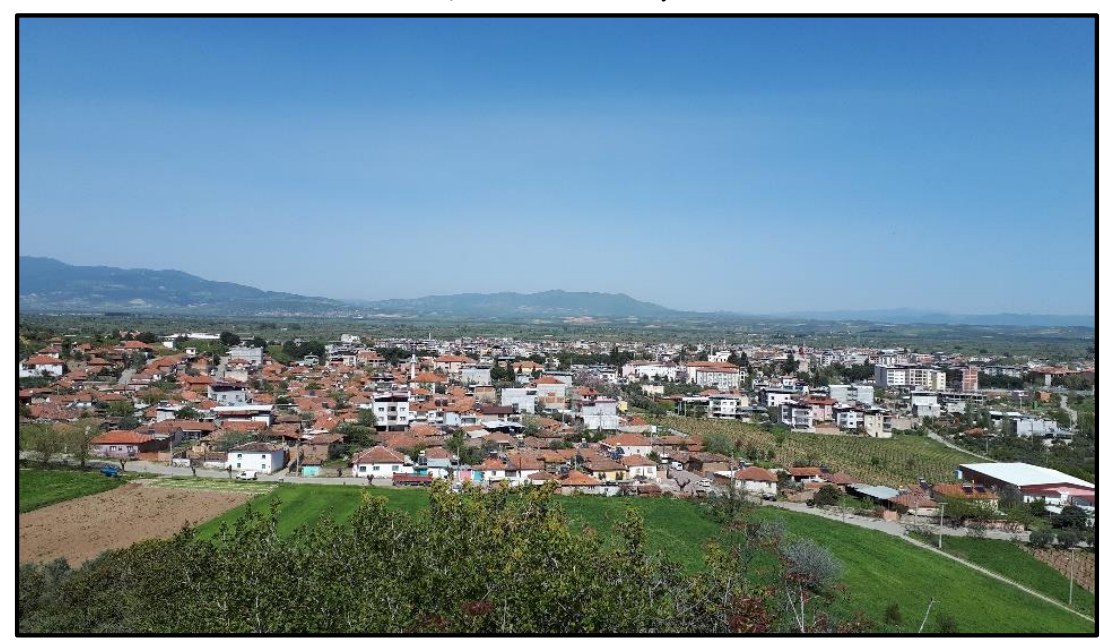

Şekil 1: Ahmetli İlçesinin Lokasyon Haritası.

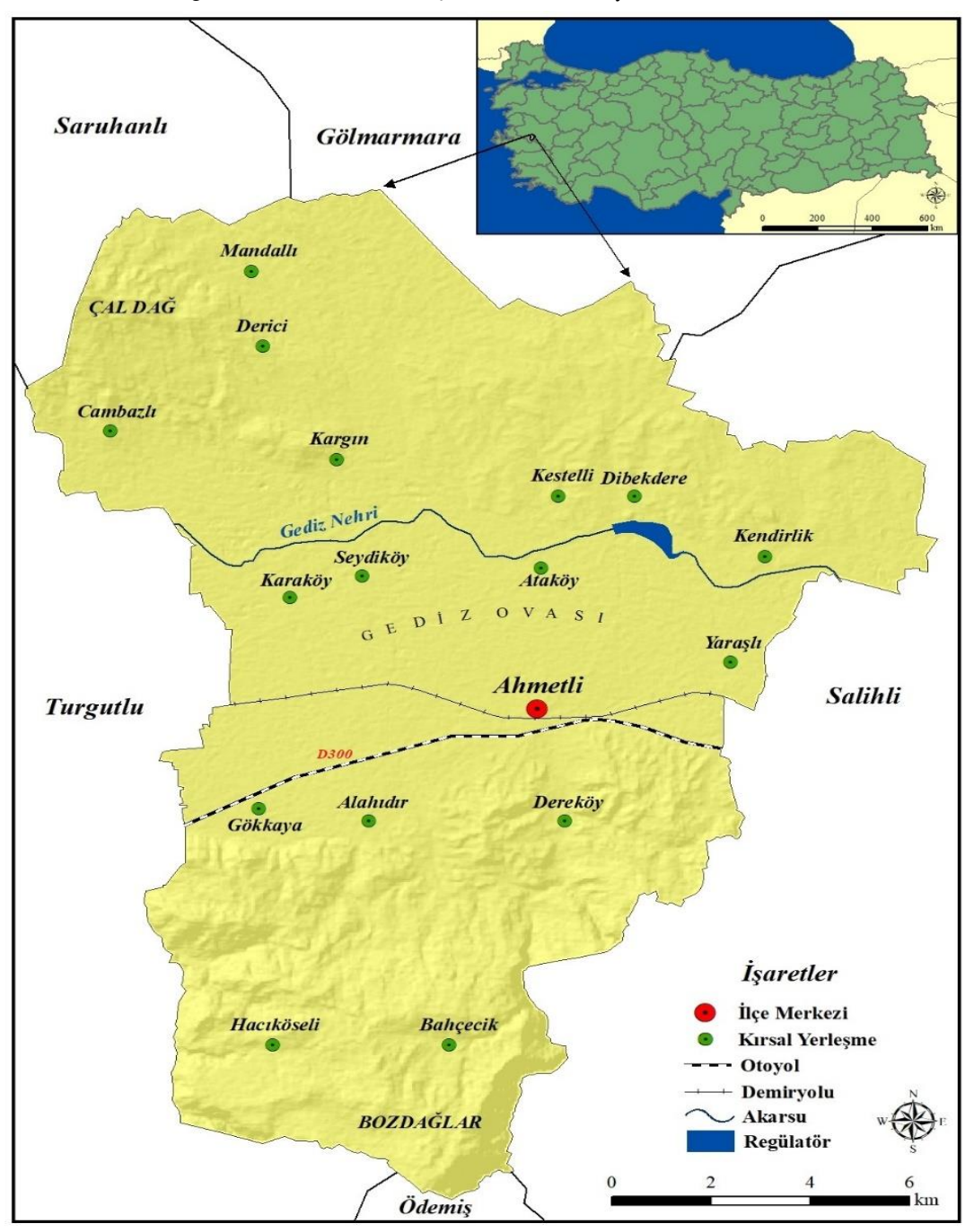




\section{Araştırma Sahasının Coğrafi Özellikleri}

Ahmetli ilçesi Gediz Havzası'nın orta bölümünde yer almaktadır. Jeolojik olarak havzanın temelini, en yaşlı birim olan Menderes Masifi'nin bir bölümünü oluşturan güneyindeki Bozdă̆ kütlesi oluşturmaktadır (Çukur, 1992, s. 8). Bozdağ kütlesi ise Palezoik şist seri ve bu serilerden daha yaşlı olan karmaşı1k gnayslardan meydana gelmiştir (Koçman, 1989, s.64). Bozdağ kütlesinin kuzey eteklerinde Turgutlu'nun doğusundan Sarıöl'ün güneyine kadar doğu batı uzantıll 400-500 metre yüksekliğinde, yaklaşık $110 \mathrm{~km}$ uzunluğunda ve genişliği 3-10 km'yi bulan Tmolos Depolar1 (Bozdağ Çakılları) bulunmaktadır (Taşlıgil, 1988, s.11). Söz konusu bu depolar, III. zamanda buradaki eski kütlenin yükselmesi ve daha sonraki süreçte sel suları ile parçalanmasıyla oluşmuştur. Ayrıca Bozdağ kütlesinin kuzey eteklerinde doğu-batı yönünde Ahmetli’nin de içinde bulunduğu Turgutlu-Salihli basamaklı fay sistemi yer almaktadır (Koçman, 1985, s.68). İlçenin kuzeyinde bulunan Çal Dağ'ın esas yapısını ise, II. zamana ait kalker ve mermer blokları oluşturmaktadır (Taşligil, 1988, s.16). Gediz depresyonunun güneyinde, Gediz Nehri'nin tali kolları tarafindan oluşturulan birikinti koni ve yelpazeleri bulunmaktadır. Ahmetli Çayı'nın oluşturduğu birikinti konisi üzerinde Ahmetli şehri yer almaktadır (Çukur, 1998, s.54.).

Ege Bölgesi içinde yer alan Ahmetli ilçesi, yazları sıcak ve kurak, kışları ise 1lık ve yağışı geçen Akdeniz ikliminin etkisi altındadır. İlçede herhangi bir meteoroloji istasyonu bulunmadığından, Manisa merkez istasyonunun uzun y1llı (1960-2016) iklim verileri kullanılmıştır. Bu verilere göre Manisa'da yıllık ortalama sıcaklık $17^{\circ} \mathrm{C}$, en fazla sıcaklık Temmuz $\left(28,2^{\circ} \mathrm{C}\right)$ ayında ve en düşük sıcaklık ise Ocak $\left(6,7^{\circ} \mathrm{C}\right)$ ayında görülmüştür. Yöreye yıllık ortalama yağış $736 \mathrm{~mm}$ düşerken, en fazla yağış Aralık (141.5), en az yağış ise Temmuz (5.4) ayında düşmüştür (Meteoroloji Genel Müdürlüğü, 2021). Sicaklık değerleri ova tabanında yüksek iken, kuzeydeki Çal Dağ ve güneydeki Bozdağlara doğru düşmektedir. Aynı şekilde yağış değerleri de kuzey ve güneydeki yükseltinin artışına bağlı olarak artmaktadır. Bölgede topografyanın doğu-batı şeklinde uzanışı denizel etkinin içeriye doğru sokulmasına sebep olmaktadır. Yaz aylarında yağışın çok az düşmesi ve sıcaklığın yüksek olması, Gediz Ovası'nda sulamalı tarımsal faaliyetlerini arttırmaktayken yükseltinin arttığ yerlerde ise daha çok dikili tarımın ön plana çıkmasını sağlamaktadır.

Toprak özellikleri, 1988 yllında Köy Hizmetleri Genel Müdürlüğü (KHGM) tarafindan hazırlanan verilerden yararlanılarak üretilmiştir. Buna göre Ahmetli ilçesinde toprakların yarısını meydana getiren en büyük toprak grubunu, \%26'lık oranla alüvyal (6039 ha) ve rendzina (6124 ha) toprakları oluşturmaktadır. Alüvyal topraklar Gediz Ovası'nda yaygın durumdayken, ovanın kuzeyine doğru alüvyal topraklardan sonra rendzinalar yaygınlık göstermeye başlamıştır. $\mathrm{Bu}$ topraklar1, \%20 oranla kahverengi orman topraklar1 (4614 ha) takip etmektedir. Kahverengi orman toprakları çoğunlukla sahanın güneyinde, Bozdağların yamaçlarında görülmektedir. İlçedeki diğer toprak grupları ise \%13 kolüvyal (2995 ha), \%7 regosol (1696 ha), \%5 kireçsiz kahverengi (1162 ha), \%2 kireçsiz kahverengi orman (412 ha) ve \%1 oranla da kırmızı Akdeniz (199 ha) topraklarıdır. Kolüvyal topraklar, Bozdağların Gediz Ovası ile birleştiği tabanda doğubatı yönlü uzanmakta iken ilçenin doğusuna doğru Bozdağların yamaçlarında kolüvyal topraklar ile kahverengi orman toprakları arasında regosoller yer almaktadır. Kireçsiz kahverengi orman toprakları genellikle Gediz Nehri yatağında bulunmaktadır. Kırmızı Akdeniz toprağı ise Gediz Ovası'nın kuzeydoğusunda küçük sahalarda kendini göstermektedir. Kireçsiz kahverengi topraklar, ilçenin doğusuna doğru Bozdağların yamaçlarında küçük alanlarda yer almaktadır (KHGM, 1998) (Şekil 2).

Arazi kullanım kabiliyet sınıfları KHGM (1998) verilerinden yararlanılarak üretilmiştir. Buna göre Ahmetli ilçesinin arazi kullanım kabiliyet sınıfları incelendiğinde en fazla arazi sınıfinı araştırma alanının yarısından fazlasını oluşturan \%27'lik oranla I. (6303 ha) ve VII. (6406 ha) sınıf araziler meydana getirmektedir. Diğer arazi sinıfları ise \%15 III. (3448 ha), \%12 IV. (2724 ha), 
\%10 VI. (2250 ha), \%8 II. (1842 ha) ve \%1 ile VIII. siniflardır. I., II., III. ve IV. sinif araziler, üzerinde tarımsal faaliyetleri yapmak için en uygun arazileri oluşturmaktadır. İlçede de tarımsal faaliyetlerin çoğunluğu söz konusu arazilerde yapılmaktadır. VI., VII. ve VIII. sınıf araziler tarımsal faaliyet için uygun araziler sınıfında bulunmamaktadır. I. sınıf araziler ilçede çoğunlukla Gediz Ovası'nın yer aldığı alanda bulunmaktadır. II., III. ve IV. sinıf araziler ise Gediz Ovası'ndaki I. sınıf arazilerin bitimiyle kuzeye doğru parçalı alanlar şeklinde yaygınlık göstermektedir. VI. sınıf arazilerin büyük kısmı Gediz Ovası'nın kuzeyinde bulunmakla birlikte güneyinde küçük alanlarda görülmektedir. VII. sınıf arazilerin çoğunluğunu Gediz Ovası'nın güneyindeki Bozdağlar kapsamakta iken, VIII. sınıf araziler ise Gediz Nehri'nin aktığ1 yatakta bulunmaktadır (KHGM, 1998), (Şekil 2).

Şekil 2: Ahmetli İlçesinde Büyük Toprak Grupları ve Arazi Kullanım Kabiliyet Sınıflarının Dağılışı.

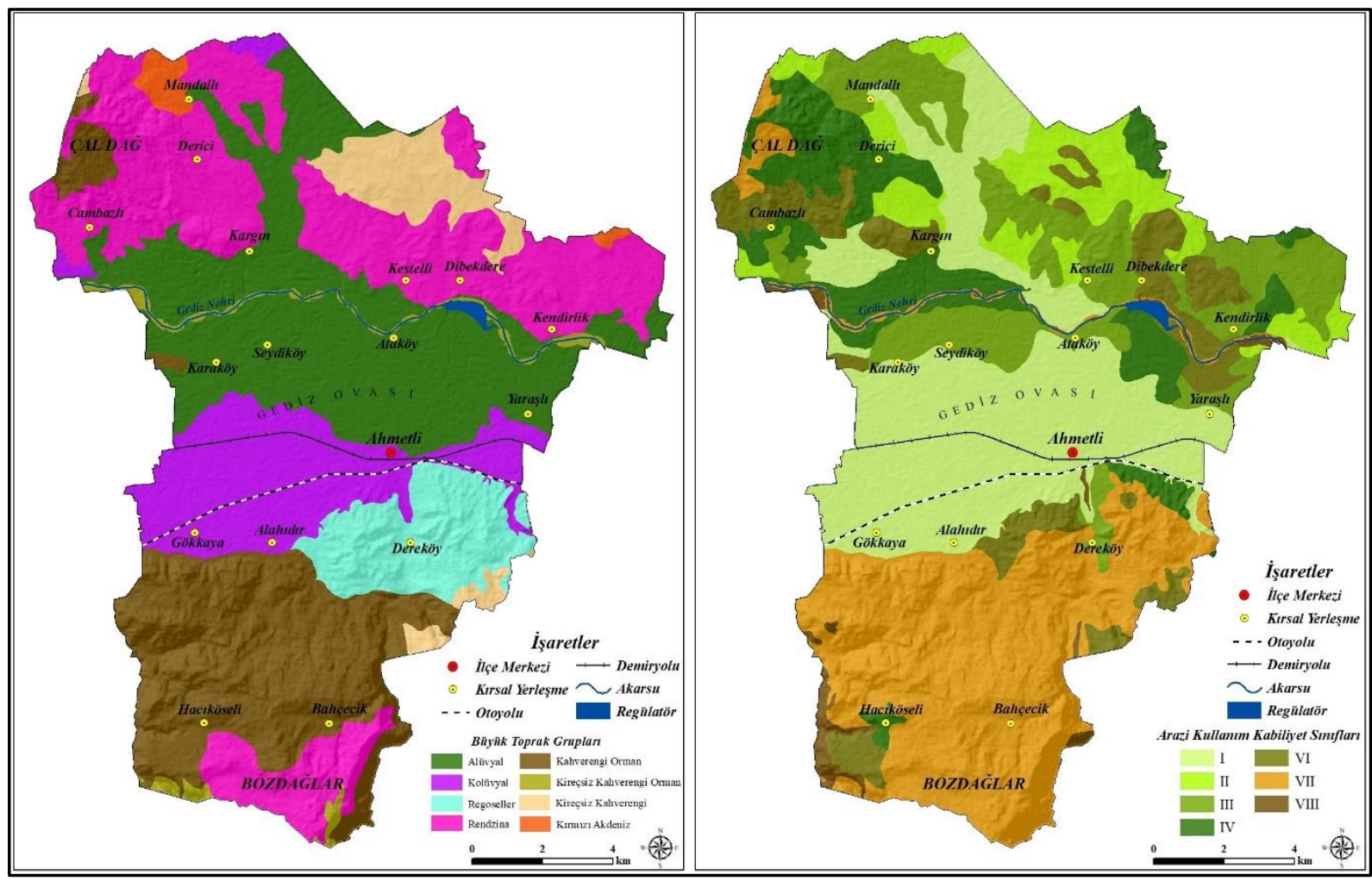

Ahmetli ilçesinde, Bozdağların güney yamaçlarında 400-500 metrelere kadar maki-garig toplulukları, bu topluluktan sonra ise 800-900 metrelere kadar kızılçam ormanları yaygınlık göstermektedir. Ahmetli Çayı'nın oluşturduğu vadide uygun bakı ve eğim şartlarına bağlı olarak maki-garig toplulukları kızılçamlarla karışık biçimde görülmektedir. 900 metrelerden sonra kızılçam ormanları, karaçam ormanları ile karışık bir şekilde kendini göstermektedir. Gediz Ovası'nın kuzeyinde yer alan Çal Dağı'nda ise maki-garig toplulukları 800 metrelere kadar çıkabilmekte, bu yükseltiden sonra kızılçam ormanları yayılış göstermektedir. Söz konusu makigarig toplulukları arasında delice zeytin, adi kocayemiş, funda, kermez meşesi, akçakesme, böğürtlen, abdest bozan gibi türler bulunmaktadır (Çukur, 1992, s. 132).

Ahmetli ilçesinin en önemli akarsuyu Gediz Nehri'dir. Gediz Nehri, kaynağını KütahyaUşak arasında yer alan Murat Dağı'ndan alıp Ege Denizi'ne dökülmektedir. Gediz Nehri'ne Bozdağlardan ve Çal Dağı'ndan birçok irili ufaklı daimî ve mevsimlik akarsu akmaktadır. Mevsimlik akarsular çoğunlukla kışları Çal Dağı'ndan akarak Gediz Nehri'ne katılmakta ve yazları kurumaktadır. Daimî akarsular ise genellikle Bozdağlardan Gediz Nehri'ne doğru akmakta ancak yazları Gediz Ovası'na girişte bazılarının suları sulama amacıyla kullanıldı̆̆ından çekilmektedir. Bozdağlardan akan önemli akarsu ise Ahmetli Çayı'dır. Ahmetli Çayı, kaynağını Bozdağlar 
üzerinde bulunan Çamyayla bölgesinden almakta ve Ahmetli ilçesinden Gediz Ovası'na açılmaktadır. Söz konusu Ahmetli Çayı üzerinde, tarımda sulama amacıyla yapımı halen devam eden Kelebek Barajı inşaatı bulunmaktadır. Gediz Nehri üzerinde, Gediz Ovası'nın sulanabilmesi amacıyla yapımı 1961 yılında tamamlanan Ahmetli Regülatörü yer almaktadır.

Ahmetli ilçesinin bulunduğu sahada, geçmişten beri Hititler, Frigyalılar, Lidyalılar, Persler, Romalılar gibi birçok medeniyet kurulmuş ve yok olmuştur. Ancak söz konusu sahada günümüze kadar sadece Lidyalıların kalıntıları kalmıştır. Ahmetli'nin varlığı, 166 Numaralı Muhasebe-i Vilayeti Anadolu Defteri'ne göre 16. yüzyılın başlarına dayanmaktadır. Bahsedilen defterde Aydın Sancağı'nın Sart Kazası'na bağlı Ahmetli köyünün yer aldığ1 ifade edilmektedir. 19. yüzyılın sonlarına doğru Ahmetli yerleşmesinden Kasaba-Alaşehir demiryolu hattının geçirilmesi, yerleşim biriminin nüfusunu arttırarak yerleşmenin büyümesine katkıda bulunmuştur (Ceylan, 2010, s. 232). Ahmetli, 1987 yılına kadar Turgutlu ilçesinin beldesi konumunda kalmıştır. 10 Haziran 1987 Tarihli 3392 Sayılı Kanun'la Ahmetli, ilçe özelliği kazanmıştır. Ahmetli ilçesinde günümüzde 1 şehir ve 16 kırsal yerleşim bulunmaktadır.

Ahmetli'nin nüfusu 1990 yllinda toplamda 19.554 kişiden meydana gelmiştir. Bu nüfusun \%51 (9.996)'i erkek, \%49 (9.558)'u kadınlardan oluşmuştur. 2000 yllında ilçenin toplam nüfusu 18.852 kişiye ulaşmış ve bunun yine \%51 (9.688)'i erkekler, \%49 (9.164)'unu kadınlar meydana getirmiştir. 2010 yllı verilerine göre toplamda 11.116 nüfusa sahip olan ilçenin \%49 (5.480)'unu erkekler, \%51 (5.636)'ini ise kadınlar oluşturmuştur. 2015 yllında ise ilçenin nüfusu, önceki döneme göre yükselerek 16.460 kişi olarak gerçekleşirken bunun \%51 (8.323)'ini erkek, \%49 (8.137)'unu kadın nüfus meydana getirmiştir. İlçenin 2020 nüfusu toplamda 16.614 kişiden oluşmuş, bu nüfusun \%50 (8.377)'sini erkekler, diğer \%50 (8.237)'sini de kadınlar oluşturmuştur (Türkiye İstatistik Kurumu, 2021). İlçe özelliğini kazandığı ilk y1llarda Ahmetli’nin nüfusunun günümüzdeki nüfusundan daha fazla olduğu görülmektedir. İlçede geçmişten beri göç olayı yaşanmakta ve bu göçün temel nedeni ekonomik faktörlere dayanmaktadır (Akbaş, 2019, s. 199). Yaşanan göç olayının diğer nedenleri arasında İzmir-Ankara ulaşımını sağlayan otoyolu ve demiryolu ulaşımının bulunması, İzmir gibi büyük bir şehre, aynı zamanda Turgutlu ve Salihli gibi gelişmiş ilçelere yakın olması gösterilebilir.

\section{Veri ve Yöntem}

Günümüzde Coğrafi Bilgi Sistemleri (CBS) ve Uzaktan Algılama (UA) uygulamalarıyla arazi örtüsü/kullanımı değişimi etkin bir biçimde belirlenebilmektedir. Dünyada ve ülkemizde arazi örtüsü/kullanımı çalışmaları iki şekilde uygulanmaktadır. Bunlar mevcut arazi durumunun belirlenmesi ve en az iki farklı görüntünün kullanılmasıyla oluşan değişimlerin bulunmasıdır (Güre vd., 2009, s. 38). Bu çalı̧smada kullanılmak üzere 15.09.1995-10.09.2005 yıllarına ait Landsat 5 TM ve 06.09.2015 y1lına ait Landsat 8 OLI uydu görüntüleri elde edilmiştir. Söz konusu uydu görüntülerinin kullanılması sonucunda arazi örtüsünün/kullanımının değişimi ortaya konulmuştur. Her bir görüntünün aynı aya ait olmasına dikkat edilmiştir. Çünkü farklı aylara ait görüntülerdeki renk yansımaları benzer olmadığından sonuçlar yanıltıcı olabilmektedir. Uydu görüntülerinin sinıflandırılmasında ve doğruluk analizi işlemlerinde CBS programlarından biri olan Arc-GIS 10.4.1 yazılımı kullanılmıştır. Yine aynı program kullanılarak araştırma sahasının lokasyon, yükselti ve eğim haritaları üretilmiştir. Lokasyon haritasının üretilmesinde yerleşme, yol, akarsu gibi faktörler için Harita Genel Müdürlüğü'nden elde edilen topoğrafya haritas1 kullanılmıştır. Yükselti ve eğim haritalarının üretilmesinde ise Aster Global Digital Elevation Model (GDEM)'den elde edilen 30 metre çözünürlüklü Digital Elevation Model (Dem) verisinden yararlanılmıştır.

Elde edilen uydu görüntüleri öncelikle sınıflandırma işlemine tabi tutulmuştur. Sınıflandırma işlemleri, kontrollü ve kontrolsüz olmak üzere iki şekilde yapılmaktadır. Kontrollü sınıflandırma işleminde araştırma alanının arazi örtüsü hakkında verilen ön bilgiler kullanılarak 
sınıflandırma için gerekli istatistikî temel oluşturulmakta ve sınıflandırma bu temel üzerine kurulmaktadır (Özdemir \& Bahadır, 2008, s. 5). Kontrolsüz sınıflandırmada ise başlangıçta arazi örtüsü ile ilgili ön bilgiye ihtiyaç duyulmadığından sadece sınıf sayısının belirlenmesi yeterli olmaktadır. Bu çalışmada, uydu görüntülerinin sınıflandırılması işleminde kontrollü sınıflandırma kullanılmıştır. Yapılan çalışmalarda (Gülersoy, 2013a, 2013b, 2014; Özşahin, 2010; Kaya ve Toroğlu, 2015) en çok kullanılan kontrollü sınıflandırma yöntemlerinden biri olan Maksimum Benzerlik (Maximum Likehood) algoritması, bu araştırmada da yöntem olarak tercih edilmiştir. Çalışmada kullanılan uydu görüntüleri yerleşim alanı (konut, yol, tesis vb.), tarım arazisi (kuru ve sulu tarım), orman ve diğer arazi (kayalık, mera, bataklık, çıplak arazi vb.) olmak üzere 4 sınıfa ayrılmıştır. Sınıflandırma işleminden sonra her bir sınıf için 50 ve toplamda 200 referans noktası belirlenerek doğruluk analizleri yapılmıştır. Söz konusu bu işlemler üç ayrı uydu görüntüsü için tekrar edilerek sonuçlar ortaya konulmuştur. Literatürde, genel doğruluk oranının 0.80’i, kappa katsayısının ise 0.75'i geçtiği çalışmalar güvenilir olarak kabul edilmektedir (Baysal, 2006, s. 56; Gürbüz vd., 2012, s. 33; Kaya ve Toroğlu, 2015, s. 90). Yapılan bu çalışmada doğruluk analizlerinin genel doğruluk oranı 0.80 'i, kappa katsayısı da 0.75 'i geçmiş ve güvenirliliği yüksek çıkmıştır.

\section{Bulgular}

Ahmetli ilçesi, toplamda 23316 hektar alandan meydana gelmektedir. İlçede yükselti değerleri 25 ile 1133 metre arasında değişmektedir. Ahmetli ilçesindeki arazinin \%40'llk kısmı 25100 metre arasındadır. Söz konusu arazinin çoğunu ise doğu-batı yönünde uzanan Gediz Ovası'nın bulunduğu alan oluşturmakta ve ilçede tarımsal faaliyetlerin büyük bölümü burada yapılmaktadır. Ahmetli ilçe merkezinin de yer aldığ1 yerleşmelerin büyük kısmı Gediz Ovası üzerinde konumlanmıştır. İlçedeki yükselti değeri kuzeyinde yer alan Çal Dağı'na ve güneyindeki Bozdağlara doğru artmaktadır. Bu alanlarda ise daha çok kuru tarım yöntemleri uygulanmakta ve tarım yapılamayan araziler makilik ve ormanlık alanlardan oluşmaktadır. İlçede en yüksek alanları oluşturan 881-1133 metre arasındaki araziler toplam alanın \%5'ini oluşturmaktadır (Tablo 1). Yükseltinin artmasıyla birlikte eğim değerleri de artmaktadır (Şekil 3).

Şekil 3: Ahmetli İlçesinin Yükselti ve Eğim Haritası.
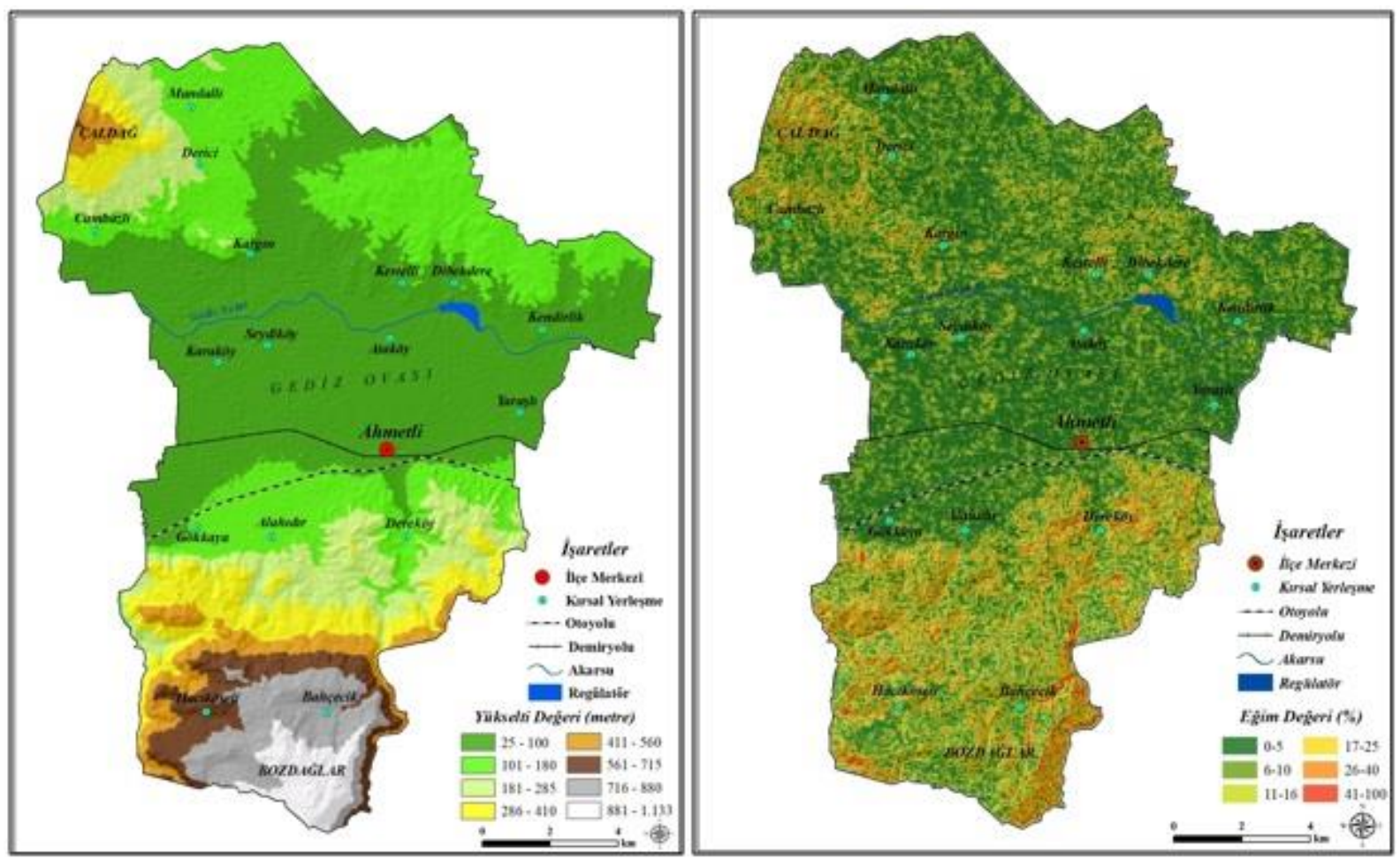
Üzülmez, M. (2021). Ahmetli (Manisa) ilçesinde arazi örtüsünün/kullanımının zamansal değişimi (19952015), Mavi Atlas, 9(2), 133-147

Tablo 1: Ahmetli İlçesinin Yükselti Değerlerinin Alansal ve Oransal Dağılımı.

\begin{tabular}{|c|c|c|}
\hline Yükselti (metre) & Hektar (ha) & Yüzde (\%) \\
\hline $25-100$ & 9288 & 27 \\
\hline $101-180$ & 6240 & 10 \\
\hline $181-285$ & 2388 & 7 \\
\hline $286-410$ & 1745 & 4 \\
\hline $411-560$ & 984 & 4 \\
\hline $561-715$ & 890 & 5 \\
\hline $716-880$ & 1191 & 3 \\
\hline $881-1133$ & 590 & 27 \\
\hline
\end{tabular}

Ahmetli ilçesinin 1995 yllına ait uydu görüntüsünden elde edilen arazi kullanım haritasına göre yerleşim alanı 760, tarım arazisi 9184, orman arazisi 2121 ve diğer arazi grubu ise toplamda 11251 hektar alandan meydana gelmiştir (Şekil 4). Söz konusu yılda arazinin çoğunu \%48 oranla diğer arazi grubu oluşturmuştur. İlçedeki arazinin geri kalanını ise $\% 40$ ile tarım arazisi, $\% 9$ ile orman arazisi ve \%3 oranında yerleşim alanı meydana getirmiştir (Tablo 2). 1995 yllı uydu görüntüsünden elde edilen arazi kullanım haritasının genel doğruluk oranı 0.88 , kappa katsayısı ise 0.85 çımıştır (Tablo 3).

Tablo 2: Ahmetli İlçesinde 1995 Yılı Arazi Kullanımının Alansal ve Oransal Dağılımı.

\begin{tabular}{|c|c|c|}
\hline Arazi Kullanımı & Hektar & Yüzde (\%) \\
\hline Yerleşim Alanı & 760 & 40 \\
\hline Tarım Arazisi & 9184 & 9 \\
\hline Orman Arazisi & 2121 & 48 \\
\hline Diğer Arazi & 11251 & 400 \\
\hline Toplam & 23316 & 4 \\
\hline
\end{tabular}


Üzülmez, M. (2021). Ahmetli (Manisa) ilçesinde arazi örtüsünün/kullanımının zamansal değişimi (19952015), Mavi Atlas, 9(2), 133-147

Şekil 4: Ahmetli İlçesinin 1995 Yllı Uydu Görüntüsü ve Arazi Kullanımı.

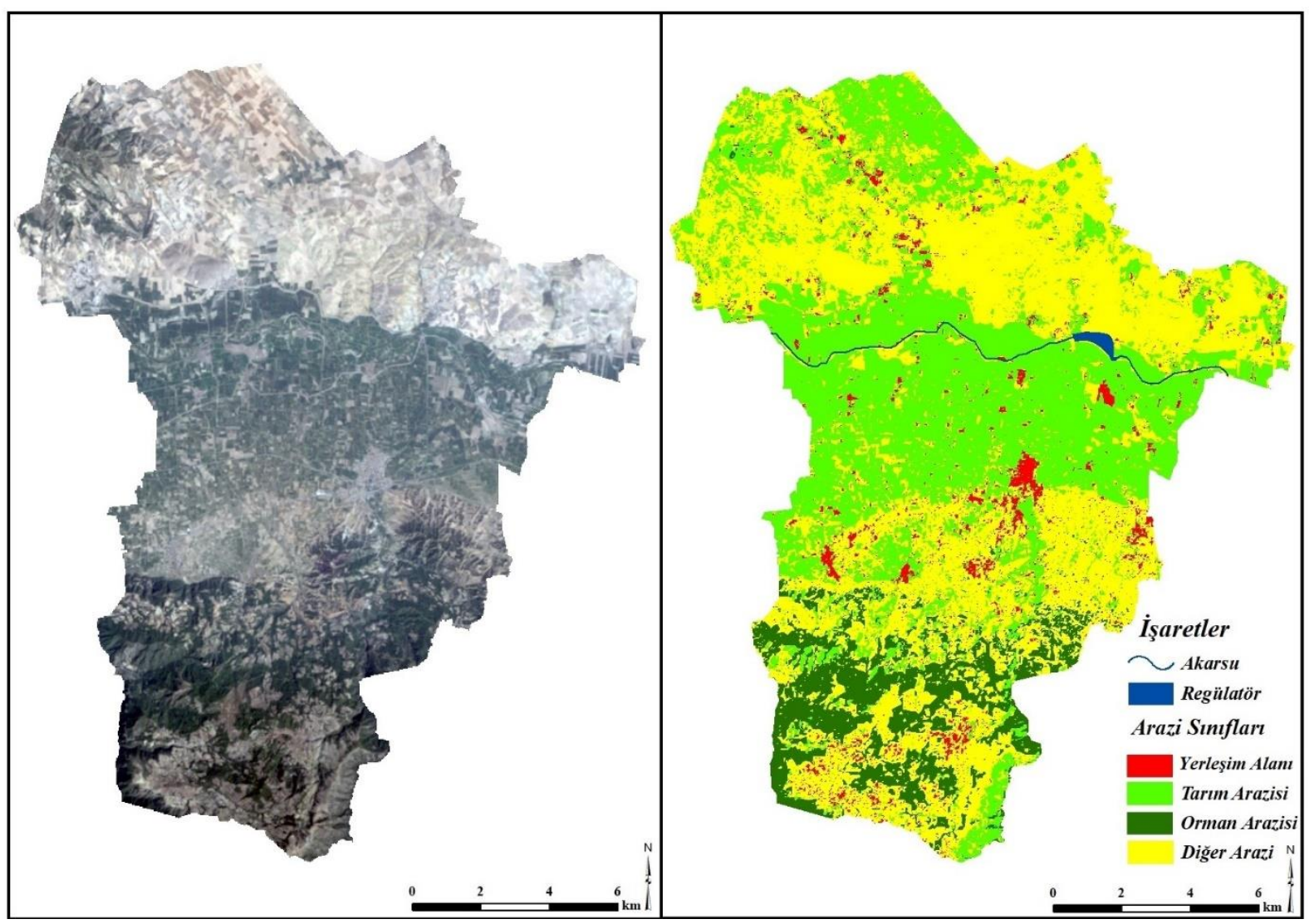

Tablo 3: 1995 Y1lı Uydu Görüntüsünün Doğruluk Analizi.

\begin{tabular}{|c|c|c|c|c|c|c|c|}
\hline Arazi Sınıfi & $\begin{array}{c}\text { Yerleşim } \\
\text { Alanı }\end{array}$ & $\begin{array}{c}\text { Tarım } \\
\text { Arazisi }\end{array}$ & $\begin{array}{c}\text { Orman } \\
\text { Arazisi }\end{array}$ & $\begin{array}{c}\text { Diğer } \\
\text { Arazi }\end{array}$ & Toplam & $\begin{array}{c}\text { Kullanıcı } \\
\text { Doğruluk }\end{array}$ & Kappa \\
\hline Yerleşim Alanı & 37 & 2 & 0 & 11 & 50 & 0.74 & 0 \\
\hline Tarım Arazisi & 1 & 45 & 0 & 4 & 50 & 0.90 & 0 \\
\hline Orman Arazisi & 0 & 0 & 50 & 0 & 50 & 1 & 0 \\
\hline Diğer Arazi & 0 & 4 & 1 & 45 & 50 & 0.90 & 0 \\
\hline Toplam & 38 & 51 & 51 & 60 & 200 & 0 & 0 \\
\hline Üretici Doğruluk & 0.97 & 0.88 & 0.98 & 0.75 & 0 & $\mathbf{0 . 8 8}$ & 0 \\
\hline Kappa & 0 & 0 & 0 & 0 & 0 & 0 & $\mathbf{0 . 8 5}$ \\
\hline
\end{tabular}

2005 yılı arazi kullanım haritasına göre arazi örtüsünde değişim yaşanmış ve yerleşim alanı bir önceki döneme göre \%4 oranında artarak 1652 hektara ulaşmıştır (Şekil 5). Söz konusu dönemde tarım arazisinde büyük değişim meydana gelmiş, tarım arazisinin toplam arazideki oranı \%40'dan \%61'e yükselerek 14255 hektar alan olarak gerçekleşmiştir. Bu dönemde orman arazisinde de aynı şekilde artış yaşanmış, kapladığı alan 3419 hektara ulaşarak önceki döneme göre \%6 oranında artmıştır. Diğer arazi grubunda ise büyük azalma gerçekleşmiş, 3990 hektara düşerek \%31 oranında azalmıştır (Tablo 4). Bu dönemde ilçede, konut alanları ve yeni yolların yapılmasıyla yerleşim alanında artış yaşanmıştır. Tarımda ise sulama olanaklarının gelişmesiyle birlikte sulanamayan verimli tarım arazileri sulanmaya başlanarak tarımsal faaliyetler artmıştır. Böylece diğer arazi grubunda yer alan boş araziler tarım arazisi içine dâhil olmuştur. Aynı şekilde yüksek kesimlerdeki tarımsal faaliyetler için zayıf olan arazilere ağaçlandırma çalışmalarının yapılmasıyla orman arazilerinin artışı sağlanmıştır. 2005 yılı uydu görüntüsünden üretilen arazi kullanım haritasının genel doğruluk oranı 0,88, kappa katsayısı ise 0,84 olarak elde edilmiştir (Tablo 5). 
Üzülmez, M. (2021). Ahmetli (Manisa) ilçesinde arazi örtüsünün/kullanımının zamansal değişimi (19952015), Mavi Atlas, 9(2), 133-147

Tablo 4: Ahmetli İlçesinde 2005 Yılı Arazi Kullanımının Alansal ve Oransal Dağılımı.

\begin{tabular}{|c|c|c|}
\hline Arazi Kullanımı & Hektar & Yüzde (\%) \\
\hline Yerleşim Alanı & 1652 & 61 \\
\hline Tarım Arazisi & 14255 & 15 \\
\hline Orman Arazisi & 3419 & 17 \\
\hline Diğer Arazi & 3990 & 100 \\
\hline Toplam & 23316 & \\
\hline
\end{tabular}

Şekil 5: Ahmetli İlçesinin 2005 Yılı Uydu Görüntüsü ve Arazi Kullanımı.

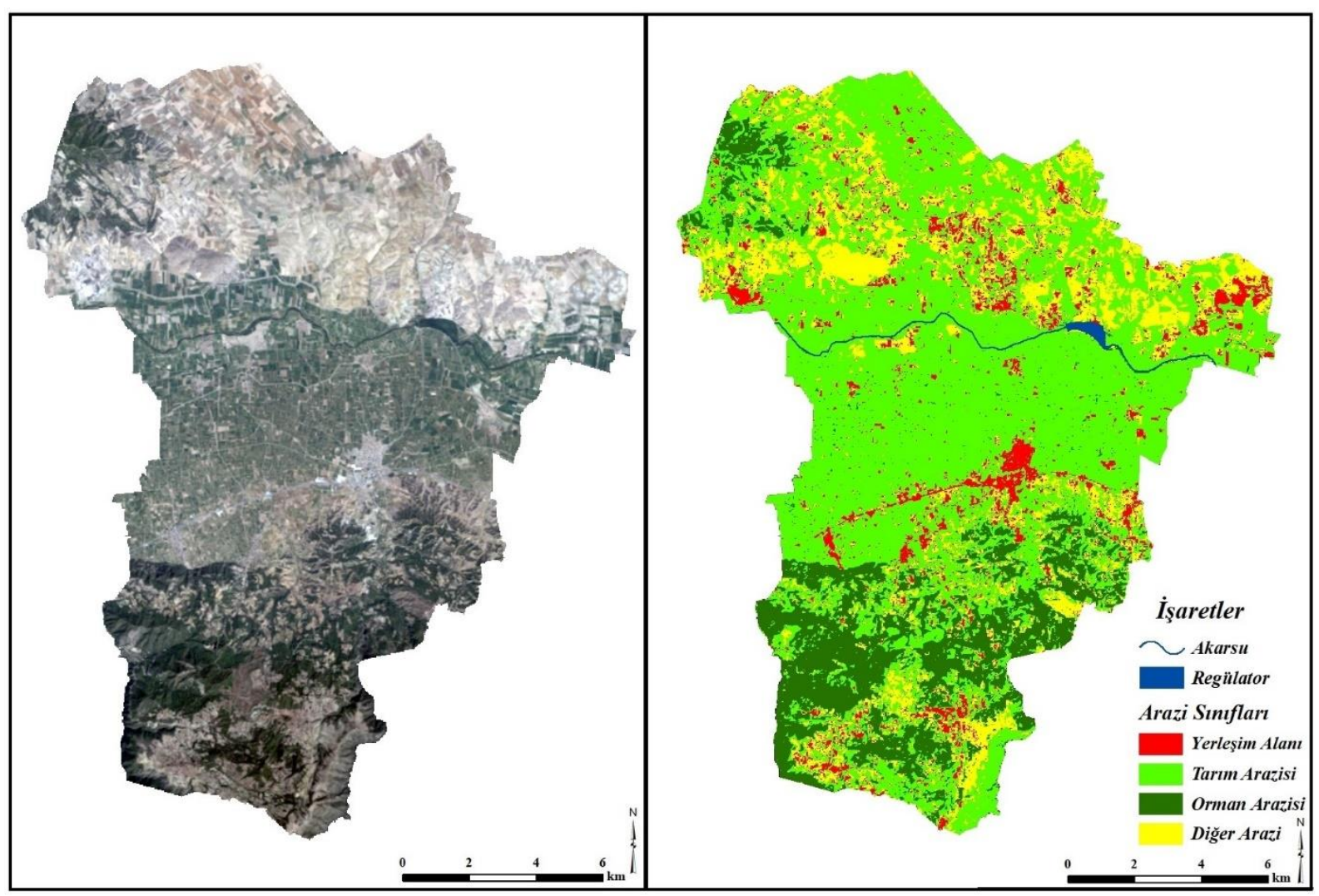

Tablo 5: 2005 Y1lı Uydu Görüntüsünün Doğruluk Analizi.

\begin{tabular}{|c|c|c|c|c|c|c|c|}
\hline Arazi Sınıfi & $\begin{array}{c}\text { Yerleşim } \\
\text { Alanı }\end{array}$ & $\begin{array}{c}\text { Tarım } \\
\text { Arazisi }\end{array}$ & $\begin{array}{c}\text { Orman } \\
\text { Arazisi }\end{array}$ & $\begin{array}{c}\text { Diğer } \\
\text { Arazi }\end{array}$ & Toplam & $\begin{array}{c}\text { Kullanıcı } \\
\text { Doğruluk }\end{array}$ & Kappa \\
\hline Yerleşim Alanı & 47 & 0 & 0 & 3 & 50 & 0.94 & 0 \\
\hline Tarım Arazisi & 9 & 32 & 0 & 9 & 50 & 0.64 & 0 \\
\hline Orman Arazisi & 0 & 0 & 50 & 0 & 50 & 1 & 0 \\
\hline Dĭ̆er Arazi & 3 & 0 & 0 & 47 & 50 & 0.94 & 0 \\
\hline Toplam & 59 & 32 & 50 & 59 & 200 & 0 & 0 \\
\hline Üretici Doğruluk & 0.79 & 1 & 1 & 0.79 & 0 & $\mathbf{0 . 8 8}$ & 0 \\
\hline Kappa & 0 & 0 & 0 & 0 & 0 & 0 & $\mathbf{0 . 8 4}$ \\
\hline
\end{tabular}

2015 y1lı uydu görüntüsünden üretilmiş olan arazi kullanım haritasına göre, arazi örtüsünde/kullanımında değişim yaşanmaya devam etmiştir (Şekil 6). Bu dönemde yerleşim alanının kapladı̆̆ı alan, önceki döneme göre \%3 oranında artış göstererek 2339 hektara ulaşmıştır. Özellikle ilçe merkezinin yer aldı̆̆ı alanın tarım arazilerine doğru büyümesi ve ilçenin kuzeyindeki 
Üzülmez, M. (2021). Ahmetli (Manisa) ilçesinde arazi örtüsünün/kullanımının zamansal değişimi (19952015), Mavi Atlas, 9(2), 133-147

sera alanlarının genişlemesi yerleşim alanının artışında rol oynamıştır. Tarım arazisinde bir önceki döneme göre kayda değer bir artış meydana gelmemiş ve kapladığı alan \%62 oranında gerçekleşmiştir. Tarım arazilerinin oranında artış yaşanmamasının nedeni, bir önceki dönemde verimli olan tarım arazilerinin çoğunun tarımsal faaliyetler için kullanılmasıdır. Orman arazisi önceki döneme göre \%4 oranında azalarak 2487 hektara gerilemiştir. Orman arazileri zamanla yangılar, ormanda tarla açma, yakın çevredeki kırsal yerleşimlerin ormanlardan yakacak elde etmesi gibi sebeplerle azalmaya başlamıştır. Diğer arazi grubuna bakıldığında oransal olarak değişiklik olmamış ancak kapladığı alan 78 hektar azalmıştır (Tablo 6). 2015 ylli uydu görüntüsünden üretilmiş olan arazi kullanım haritasının genel doğruluk oranı 0,89, kappa katsayısı ise 0,86 olarak gerçekleşmiştir (Tablo 7).

Tablo 6: Ahmetli İlçesinde 2015 Yıll Arazi Kullanımının Alansal ve Oransal Dağılımı.

\begin{tabular}{|c|c|c|}
\hline Arazi Kullanımı & Hektar & Yüzde (\%) \\
\hline Yerleşim Alanı & 2339 & 10 \\
\hline Tarım Arazisi & 14578 & 62 \\
\hline Orman Arazisi & 2487 & 11 \\
\hline Diğer Arazi & 3912 & 17 \\
\hline Toplam & 23316 & 100 \\
\hline
\end{tabular}

Şekil 6: Ahmetli İlçesinin 2015 Yllı Uydu Görüntüsü ve Arazi Kullanımı.

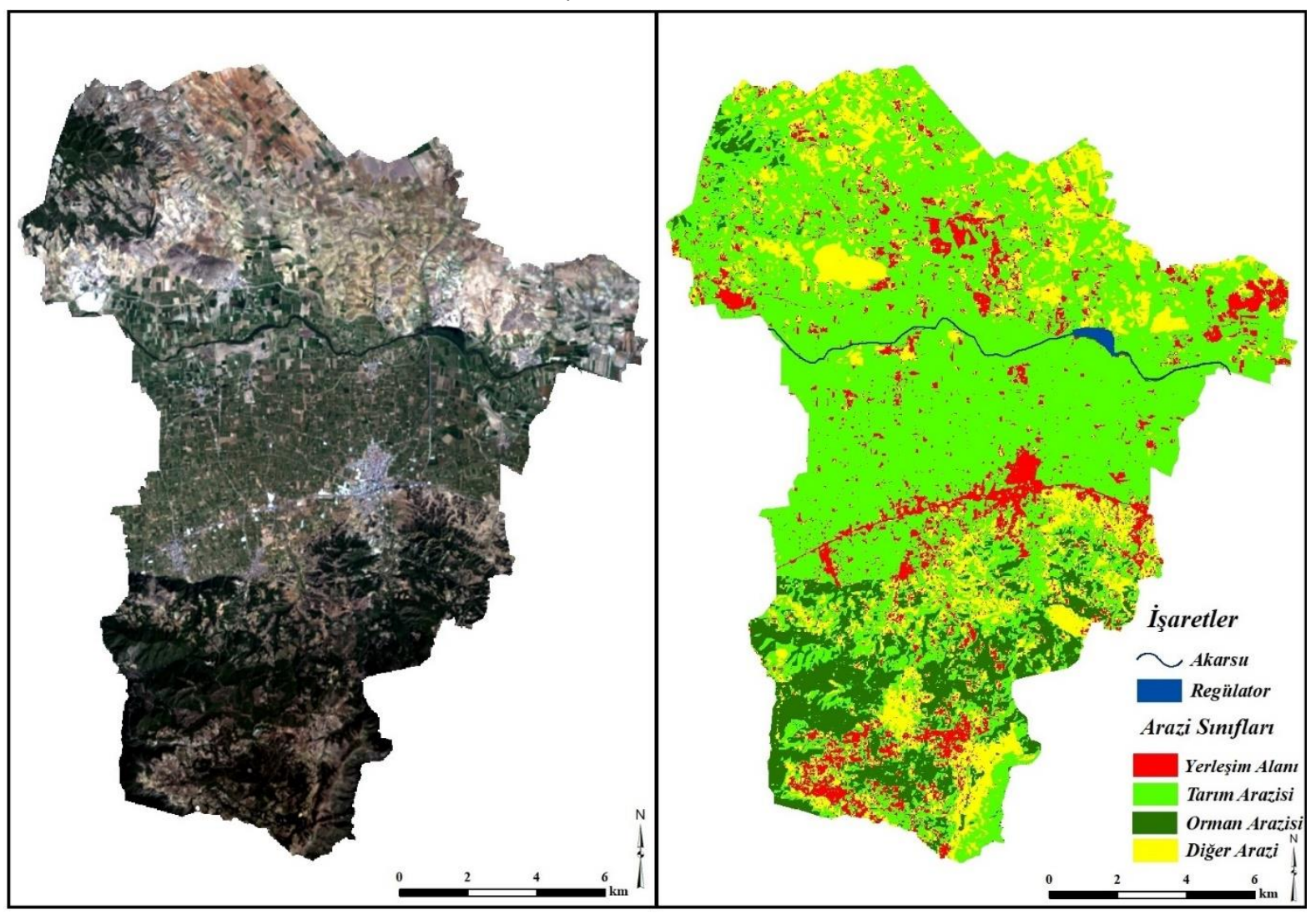


Üzülmez, M. (2021). Ahmetli (Manisa) ilçesinde arazi örtüsünün/kullanımının zamansal değişimi (19952015), Mavi Atlas, 9(2), 133-147

Tablo 7: 2015 Y1lı Uydu Görüntüsünün Doğruluk Analizi.

\begin{tabular}{|c|c|c|c|c|c|c|c|}
\hline Arazi Sınıfi & $\begin{array}{c}\text { Tarım } \\
\text { Arazisi }\end{array}$ & $\begin{array}{c}\text { Yerleşim } \\
\text { Alanı }\end{array}$ & $\begin{array}{c}\text { Orman } \\
\text { Arazisi }\end{array}$ & $\begin{array}{c}\text { Diğer } \\
\text { Arazi }\end{array}$ & Toplam & $\begin{array}{c}\text { Kullanıcı } \\
\text { Doğruluk }\end{array}$ & Kappa \\
\hline Tarım Arazisi & 34 & 6 & 0 & 10 & 50 & 0.68 & 0 \\
\hline Yerleşim Alanı & 0 & 46 & 0 & 4 & 50 & 0.92 & 0 \\
\hline Orman Arazisi & 0 & 0 & 50 & 0 & 50 & 1 & 0 \\
\hline Diğer Arazi & 1 & 0 & 0 & 49 & 50 & 0.98 & 0 \\
\hline Toplam & 35 & 52 & 50 & 63 & 200 & 0 & 0 \\
\hline Üretici Doğruluk & 0.97 & 0.88 & 1 & 0.77 & 0 & $\mathbf{0 . 8 9}$ & 0 \\
\hline Kappa & 0 & 0 & 0 & 0 & 0 & 0 & $\mathbf{0 . 8 6}$ \\
\hline
\end{tabular}

Ahmetli ilçesinin 1995-2015 yılları arasındaki arazi örtüsü/kullanımı incelendiğinde, 20 yılda yerleşim alanı 760 hektardan 2339 hektara yükselerek toplamda 1579 hektar artmıştır. Yerleşim alanındaki artış \%208 oranında gerçekleşmiştir. Aynı şekilde tarım arazisinin alanı, söz konusu süreçte 9184 hektardan 14578 hektara ulaşarak toplamda 5394 hektar artmıștır. Tarım arazisinin alanındaki artış oranı \%59'a ulaşmıştır. 20 yıllık sürede orman arazisinin alanı, 366 hektar artarak 2121 hektardan 2487 hektara yükselmiş ve \%17 oranında artış göstermiştir. Diğer arazi grubunun alanı ise, 11251 hektardan 3912 hektara düşmüş ve \%188 oranında azalmıştır. Söz konusu arazi grubunun bu süreçteki 7339 hektarlık alanı, çoğunlukla yerleşim alanı ve tarım arazisine dönüşmüştür (Şekil 7).

Şekil 7: Ahmetli İlçesinin Yıllara Göre Arazi Kullanımı (1995-2015).

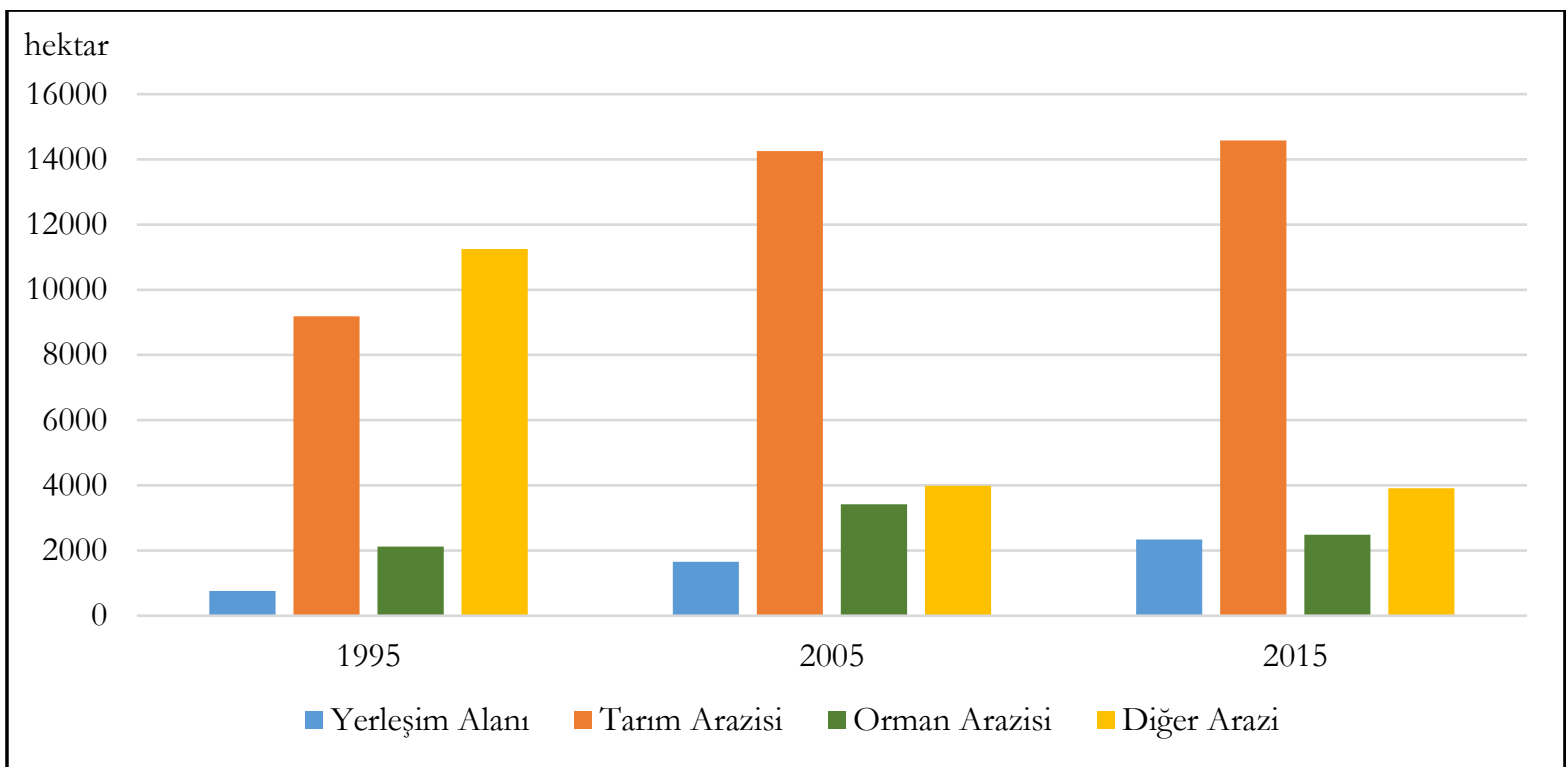

\section{Sonuç ve Öneriler}

Ahmetli ilçesi, Türkiye'nin en verimli ovalarından olan Gediz Ovası'nda yer almaktadır. İlçenin güneyinde Bozdağlar, kuzeyinde de Çal Dağ bulunmaktadır. Söz konusu alanda, geçmişten günümüze birçok medeniyet kurulmuş, gelişmiş ve yok olmuştur. İlçedeki yerleşimlerin çoğu Gediz Ovası'nda yer almış/almakta ve zamanla bu ova üzerinde büyümelerini sürdürmüşler/sürdürmektedirler. İlçenin en büyük yerleşimi ve ilçe merkezi olan Ahmetli şehrinin kuruluşu 16. yüzyıla kadar gitmektedir. Köy olarak kurulmuş olan bu şehrin gelişimi esas itibariyle ilçeden 19. yüzyılda geçen demiryolunun varlı̆̆ına dayanmaktadır. Ahmetli, 1987 yılına kadar da Turgutlu ilçesinin bir beldesi olarak gelişimini sürdürmüş ve bu tarihten sonra ilçe olarak Turgutlu'dan ayrılmıştır. Ahmetli ilçesi, yıllardır göç veren bir ilçe konumundadır ve bu göçlerin 
temeli genelde ekonomik faktörlere dayanmaktadır. Bu faktörlerin yanında ilçenin içinden geçen İzmir-Ankara ulaşımını sağlayan demiryolu ve otoyolu gibi ulaşım ağları ile iş, eğitim, sağlık gibi imkânların daha fazla olduğu Turgutlu ve Salihli gibi kendisinden daha büyük şehirlere yakınlığ1 da ilçeden göçleri tetikleyen sebepler arasında bulunmaktadır.

Ahmetli'nin ayrı bir ilçe statüsüne çıkmasından sonra ilçenin arazi örtüsünde/kullanımında yıllar itibariyle değişimler olmuştur. 1995 yılında ilçede \%3 oranında yer kaplayan yerleşim alanı, 2005 yılında \%7’ye, 2015 yılında da \%10’a ulaşmıştır. 1995 yılında ilçenin \%40'ını kaplayan tarım arazileri, 2005 yllında \%61'e, 2015 yllında \%62'ye yükselmiștir. Orman arazilerinin alanı ise 1995 'de \%9 iken, 2005'de \%15 olarak gerçekleșmiș ancak 2015'de \%11'e düşmüştür. Diğer arazi grubunun alanı, 1995 yllında ilçenin \%48’ini kaplarken bu alan 2005 y1lında \%17'ye düşmüş ve 2015'de değişmeyerek \%17 oranında kalmıştır. Yıllar itibariyle uydu görüntülerinden incelenen arazi kullanımına göre yerleşim alanında toplam \% $\%$, tarım arazisinde $\% 22$, orman arazisinde $\% 2$ oranında artış görülürken, diğer arazilerde ise $\% 31$ oranında azalış olduğu tespit edilmiştir. Bu durum, yerleşim alanının büyük kısmının tarım arazilerinin üzerinde bulunduğu ve yine bu yapıların söz konusu arazilere doğru büyüdüğ̈n̈ü göstermektedir. Tarım arazileri ve orman arazilerindeki büyümenin nedeni ise sulamanın, teknolojinin, ağaçlandırma faaliyetlerinin artmasından kaynaklanmaktadır. Diğer arazi grubundaki düşüş ise bu gruptaki arazilerin tarım ve orman arazilerine dönüştügünü göstermektedir.

Gediz Ovası gibi verimli tarım arazileri üzerinde yer alan yerleşmelerin kontrollü bir şekilde büyümesinin planlanması gerekmektedir. Söz konusu ovanın güneyinde bulunan Ahmetli şehrinin mekânsal büyümesi dikkate alındığında, şehrin gelişim alanı özellikle D300 otoyolunun güneyine, Bozdağ’ın eteklerine doğru planlanmalıdır. Aksi takdirde şehrin alanı, kuzeye yani ova tabanına doğru yayılacak ve verimli tarım arazileri yok olacaktır. Ayrıca Bozdağ ve Çal Dağ'da diğer arazi grubundaki boş alanların ağaçlandırma faaliyetlerine devam edilmelidir ve orman arazilerinin artışı sağlanmalıdır. Günümüzde gelişen sulama ve teknoloji imkânlarının neticesinde yararlanılabilecek boş arazilerin kalmaması gerekmektedir. Söz konusu imkânlar, özellikle yükseltinin arttığı verimli alanlarda dikili tarım faaliyetlerinin yapılabilmesi için kullanılmalıdır. Böylece verimli arazilerden tarımsal amaçlı daha fazla yararlanılması sağlanacaktır.

\section{Kaynaklar}

Akbaş, F. (2019). Ahmetli ilçesinde nüfus hareketleri. Atatürk Üniversitesi Edebiyat Fakültesi Dergisi, 62, 177-200.

Arslan, F. \& Ergül, M. (2014). Çaygören barajı sulama havzası ve çevresinde tarım faaliyetler. Akademik Sosyal Araștırmalar Dergisi, 2, 171-190. http://dx.doi.org/10.16992/ASOS.63

Arslan, F. (2018). Tuğla ve kiremit sanayisinin arazi kullanımına etkisi: Turgutlu örneği. Uluslararası Turgutlu Sempozyити Bildiriler Kitabı 2, (ss. 961-984), Turgutlu Belediyesi Yayınları.

Bakırcı, M. (2016). Barajların mekânın yeniden organizasyonuna etkileri: Melen Baraj1 örneği. Marmara Coğrafya Dergisi, 33, 439-464.

Bayar, R. \& Karabacak, K. (2017). Ankara ili arazi örtüsü değişimi (2000-2012). Coğrafi Bilimler Dergisi, 15(1), 59-76.

Baysal, D. (2006). Eskişehir kentsel yerleșim alanmm farkh yullara ait fiziksel değisiminin uzaktan algilama yöntemi ile değerlendirilmesi (Tez No. 181575) [Yüksek lisans tezi, Anadolu Üniversitesi]. YÖK Ulusal Tez Merkezi.

Cengiz, E. Ö., Çavuş, C. Z. \& Koç, T. (2014). Çanakkale ve Kepez yerleşmelerinde sulu tarım alanları kentleşme ilişkisi. Coğrafi Bilimler Dergisi, 12(1), 69-88.

Ceylan, M. A. (2010). Manisa-Uşak demiryolu ulaşımının yerleşme üzerine etkileri (I). Doğu Coğrafya Dergisi, 15(23), 223-249. 
Çukur, H. (1992). Orta Gediz Havzası'nm firikei coğrafyası (Tez No. 21389) [Yüksek lisans tezi, Dokuz Eylül Üniversitesi]. YÖK Ulusal Tez Merkezi.

Çukur, H. (1998). Ege Bölümü'nün ekosistemleri (Tez No. 72851) [Doktora tezi, Dokuz Eylül Üniversitesi]. YÖK Ulusal Tez Merkezi.

Demirağ Turan, İ. \& Dengiz, O. (2014). Uzaktan algilama ve coğrafi bilgi sistem teknikleri kullanılarak arazi örtüsü / arazi kullanımı zamansal değissimin belirlenmesi: Samsun Merkez ilçesi Örneği (1984-2011). Türk Tarmsal Araștırmalar Dergisi, 1, 78-90.

Gülersoy, A. E. (2001). Gömeç Ovasi'nda bugünkü araz̧i kullanım ile araz̧i smeflandırlması arasindaki iliskiler (Tez No. 103840) [Yüksek Lisans tezi, Dokuz Eylül Üniversitesi]. YÖK Ulusal Tez Merkezi.

Gülersoy, A. E. (2013a). Marmara gölü yakın çevresindeki arazi kullanım faaliyetlerinin zamansal değişimi (1975-2011) ve göl ekosistemine etkileri. Türk Coğrafja Dergisi, 61, 31-44.

Gülersoy, A. E. (2013b). Çorum Merkez ilçede arazi kullanımının zamansal değişimi (1987-2011) ve çevresel etkileri. Coğrafi Bilimler Dergisi, 11(2), 169-194.

Gülersoy, A. E. (2013c). Farklı uzaktan algilama teknikleri kullanılarak arazi örtüsü/kullanımında meydana gelen değişimlerin incelenmesi: Manisa Merkez ilçesi örneği (19862010). Turkish Studies, 8(8), 1915-1934.

Gülersoy, A. E. (2014). Seferihisar'da arazi kullanımının zamansal değişimi (1984-2010) ve ideal arazi kullanımı için öneriler. SDÜ Fen Edebiyat Fakültesi Sosyal Bilimler Dergisi, 31, 155-180.

Gürbüz, M., Denizdurduran, M., Karabulut, M. \& Kiz1lelma, Y. (2012). Uzaktan algilama ve CBS kullanarak Elbistan Ovası'nda arazi kullanımı/arazi örtüsünde meydana gelen değişimlerin incelenmesi. KSU Mühendislik Bilimleri Dergisi Özel Sayı, 30-37.

Güre, M., Özel, M.E. \& Özcan, H. (2009). Corine arazi kullanımı sınıflandırma sistemine göre Çanakkale ili. Harran Üniversitesi Ziraat Fakültesi Dergisi, 13(3), 37-48. https://hdl.handle.net/20.500.12507/105.

Kara, H. (1988). Çukurova'da kentleşme ve sanayileşmenin tarım topraklarına etkisi. Ankara Üniversitesi Dil ve Tarih-Coğrafya Fakültesi Dergisi, 32(1-2), 267-281.

Kaya, Ö. \& Toroğlu, E. (2015). Kayseri'nin şehirsel gelişiminin izlenmesi ve değişim analizi. Türk Coğrafya Dergisi, 65, 87-96.

Koçman, A. (1985). İzmir-Bozdağlar yöresinin yapısal jeomorfolojisi ve evrimi. Ege Coğrafya Dergisi, 3, 63-86.

Koçman, A. (1989). Uygulamah fiæiki coğrafya çalşsmalar ve İzmir Bozdağlar yöresi üzerinde araştırmalar. Ege Üniversitesi Edebiyat Fakültesi Yayınları.

Köy Hizmetleri Genel Müdürlügü (1998). Manisa ili arąi varlğ̆. Köy Hizmetleri Genel Müdürlüğü Yayınları.

Meteoroloji Genel Müdürlüğü (2021). Manisa ili iklim verileri. Devlet Meteoroloji Genel Müdürlüğü.

Özcanlı, M. \& Güzel, A. (2015). Şanlıurfa șehrinin alansal gelişiminin çevresindeki tarım arazilerine etkisi. Turkish Studies, 10(6), 723-744. http://dx.doi.org/10.7827/TurkishStudies.7890.

Özdemir, M. A. \& Bahadır, M. (2008). Yalova ilinde arazi kullanımının zamansal değişimi (1992-2007). İstanbul Üniversitesi Fen Edebiyat Fakültesi Coğrafya Dergisi, 17, 1-15.

Özdemir, M.H., Özav, L. \& Yasak, Ü. (2020). Örnek köyden kente dönüşen Etimesgut'ta fonksiyonel arazi kullanımının değişimi. Doğu Coğrafya Dergisi 25(44), 163-183.

Özşahin, E. (2010). İskenderun Akaçlama Havzası'nda (Hatay) arazi örtüsünün zamansal değişimi. Turkish Studies, 5(2), 1296-1320. http://dx.doi.org/10.7827/TurkishStudies.1348 
Üzülmez, M. (2021). Ahmetli (Manisa) ilçesinde arazi örtüsünün/kullanımının zamansal değişimi (19952015), Mavi Atlas, 9(2), 133-147

Sandal, E. K. \& Gürbüz, M. (2003). Mersin şehrinin mekansal gelişimi ve çevresindeki tarım alanlarının amaç dışı kullanımı. Coğrafi Bilimler Dergisi, 1(1), 117-130. https://doi.org/10.1501/Cogbil_0000000024

Sönmez, M. E. (2011). Adana şehrinin alansal gelişimi ve yakın çevresinin arazi kullanımında meydana gelen değişimler. Türk Coğrafya Dergisi, 57, 55-69.

Taşlıgil, N. (1988). Manisa ovalar ve çevresi (Tez No. 9748) [Doktora tezi, İstanbul Üniversitesi]. YÖK Ulusal Tez Merkezi.

Türkiye İstatistik Kurumu (2021). Adrese dayah nüfus kaynt sistemi sonuclar.

Uzun, A. \& Somuncu, M. (2013). Madra Dağı ve çevresinin arazi örtüsü/kullanımındaki zamansal değişimin uzaktan algılama yöntemi ile değerlendirilmesi. Bahkesir Üniversitesi Sosyal Bilimler Enstitüsü Dergisi, 16(30), 1-21.

Yılmaz, A. (2004). Samsun kentinin yeni gelişim alanları: Atakum, Atakent ve Kurupelit. Türk Coğrafya Dergisi, 42, 59-72.

Yılmaz, Ö. (2001). Tarım alanlarının amaç dışı kullanımı ve Afyon örneği. Afyon Kocatepe Üniversitesi Sosyal Bilimler Dergisi, 3(1), 151-164. https://sbd.aku.edu.tr/III1/13.pdf. 